\begin{tabular}{|c|c|}
\hline 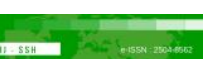 & Malaysian Journal of Social Sciences and Humanities (MJSSH) \\
\hline Malaysian Journal of & Volume 6, Issue 3, March 2021 \\
\hline (MJ-SSH) & e-ISSN : 2504-8562 \\
\hline & $\begin{array}{l}\text { Journal home page: } \\
\text { www.msocialsciences.com }\end{array}$ \\
\hline
\end{tabular}

\title{
Intervensi Mindfulness dalam Meningkatkan Perhatian Selektif Murid di Sekolah Rendah
}

\author{
Raymond Teh Li Xien ${ }^{1}$, Faridah Binti Mydin Kutty ${ }^{1}$ \\ ${ }^{1}$ Fakulti Pendidikan, Universiti Kebangsaan Malaysia (UKM) \\ Correspondence: Faridah Binti Mydin Kutty (faridah_mydin@ukm.edu.my)
}

\begin{abstract}
Abstrak
Murid-murid yang menghadapi masalah menumpukan perhatian akan menjejaskan pencapaian akademik mereka di dalam kelas. Intervensi mindfulness berupaya sebagai penyelesaian yang alternatif untuk meningkatkan kemahiran perhatian mereka terutamanya perhatian selektif mereka. Kajian ini bertujuan untuk menguji keberkesanan intervensi mindfulness dalam kalangan murid sekolah rendah dalam meningkatkan kemahiran selektif murid dengan reka bentuk kajian eksperimental. Kajian ini melibatkan 22 orang murid tahun 6 di sekolah rendah dengan membahagikan mereka kepada kumpulan rawatan dan kumpulan kawalan. Perhatian selektif responden sebelum dan selepas intervensi diukur dengan menggunakan perisian komputer iaitu ujian Stroop dan ujian pencarian visual conjunction (CVS). Data kajian dianalisis dengan menggunakan analisis deskriptif dan inferensi untuk melihat keberkesanan intervensi mindfulness terhadap perhatian selektif. Hasil kajian menunjukkan peningkatan yang signifikan dalam kedua-dua instrumen perhatian pada kumpulan rawatan pada masa tindak balas iaitu $(\mathrm{F}=17.631, \mathrm{p}<.05)$ pada ujian Stroop dan $(\mathrm{F}=4.98, \mathrm{p}<.05)$ pada ujian CVS. Dapatan kajian ini dapat memberi implikasi kepada guru-guru atau ibu bapa untuk membantu murid-murid sekolah rendah yang bermasalah pembelajaran yang berpunca daripada kekurangan perhatian selektif.
\end{abstract}

Kata kunci: mindfulness, perhatian selektif, murid sekolah rendah

\section{The Effects of Mindfulness on Selective Attention Among Primary School Children}

\begin{abstract}
The academic performance of a pupil will be affected when they have difficulty concentrating. The mindfulness intervention have been proven by several studies to have a positive effect on improving students' attention skills with specific techniques such as counting on breath. The use of this intervention is an alternative solution to improve pupils' attention skills especially in the area of their selective attention skills. This study aims to examine the effectiveness of the mindfulness intervention among primary school students in improving their selective attention skills with experimental research design. The study involved twenty-two Year 6 primary school pupils. They were divided into treatment and control groups. The respondents' selective attention before and after the intervention were measured and collected by using the computerized Stroop test and conjunction visual search test (CVS). The present study used descriptive and inferential analysis to observe the effectiveness of the mindfulness intervention on selective attention. The findings of the study reflected significant improvement in both instruments of attention in the treatment groups, especially for time of response of the instrument which are $(\mathrm{F}=17.631, \mathrm{p}<.05)$ on the Stroop test and $(\mathrm{F}=4.98, \mathrm{p}<.05)$ on the CVS test. The findings from this
\end{abstract}


study can be used to benefit educators' in their teaching pedagogy, helping them to better manage and support pupils with attentional challenges.

Keywords: mindfulness, selective attention, primary school pupils

\section{Pengenalan}

Kognisi boleh ditakrifkan sebagai proses mental semasa menjalankan aktiviti mentafsir, mempelajari dan memahami sesuatu ilmu pengetahuan, pengalaman yang baharu untuk memahami sesuatu, membuat keputusan serta menghasilkan sesuatu tindakan yang berkenaan (Bruya, 2010). Dalam penyelidikan bidang kognisi, salah satu aspek yang selalu dikaitkan adalah perhatian (Solso, 2005). Perhatian boleh didefinisikan sebagai sensasi yang difokuskan untuk mendapatkan sesuatu maklumat yang spesifik (Posner \& Boies, 1971). Perhatian membantu seseorang itu mengurangkan atau meminimumkan informasi, persepsi atau sensasi yang tidak relevan (Treisman, 1969) Perhatian merupakan salah satu kemahiran yang asas dalam fungsi kognitif manusia (Cooley \& Morris, 1990). Pada era teknologi digital ini, kajian menyatakan bahawa tabiat menjalankan pelbagai tugas (multitasking) juga menyebabkan seseorang itu sukar mengekalkan perhatiannya (Baumgartner \& Sumter, 2017). Berdasarkan kepada kajian oleh Baumgartner dan Sumter (2017), didapati 80\% daripada 361 orang responden tidak dapat mengekalkan perhatian mereka kepada tugasan yang diberi dan perhatian mereka akan teralih kepada media yang lain dalam hanya masa 10 minit.

Dalam konteks pendidikan, salah satu aspek yang sering dikaji dalam kemahiran perhatian adalah perhatian selektif (Jensen, et al, 2012). Perhatian selektif merupakan salah satu komponen yang penting dalam kemahiran perhatian. Perhatian selektif ini berfungsi untuk memilih informasi yang relevan daripada pelbagai informasi yang tidak relevan (Kartik, 2007). Murid-murid menghadapi masalah menumpu perhatian kerana mereka selalu menjalankan pelbagai tugasan pada masa yang sama (multitasking behavior) seperti melayari internet, bermain dengan permainan video, menonton televisyen menyebabkan mereka berhadap dengan informasi-informasi yang terlampau banyak (Napoli, et al, 2005). Memberikan perhatian amat penting kepada pelajar-pelajar dari aspek pencapaian akademik, perkembangan sosial dan perkembangan individu (Su \& Swank, 2019). Salah satu cabaran yang dihadapi oleh guru-guru sekolah zaman sekarang adalah membantu murid mengekalkan atau menarik perhatian murid-murid supaya berfokus kepada proses pengajaran dan pembelajaran. Fenomena ini telah menunjukkan bahawa terdapat keperluannya untuk menangani isu ini supaya tidak memberi impak yang negatif terutamanya penjejasan terhadap pencapaian akademik mereka di sekolah.

Salah satu aspek yang sering dikaji untuk meningkatkan kesejahteraan murid di sekolah adalah amalan mindfulness. Teknik intervensi mindfulness melalui pernafasan yang sistematik dipercayai dapat meningkatkan perhatian seseorang individu itu (Napoli et al, 2005). Amalan mindfulness telah menjadi semakin popular di seluruh dunia (Decker et al, 2019). Konsep mindfulness amat berkait dengan kemahiran perhatian (Napoli et al, 2005). Mindfulness bererti menumpu perhatian terhadap sesuatu perkara dan mengalami keterangan pada ketika itu (Kabat-Znn, 1994). Kajian-kajian mindfulness masih tidak meluas di Malaysia (Ramli, H., 2018). Di Malaysia, konsep mindfulness diajar untuk membantu pelajar-pelajar perubatan atau pelajar universiti untuk menangani masalah stres (Phang et al, 2016; Ramli, 2018). Intervensi mindfulness yang digunakan untuk membantu pelajar-pelajar dewasa terutamanya dalam mengawal emosi atau mengurangkan stres. Di Malaysia, terdapat pelbagai intervensi untuk meningkatkan perhatian murid-murid di sekolah seperti pendekatan origami (Ali \& Sahal, 2016), teknik bermain (Nachiappan et al., 2017), penggunaan teknologi komunikasi dan maklumat (Ahmad, 2016). Namun, kajian yang berkenaan dengan amalan mindfulness dalam konteks sekolah rendah di negara kita masih tidak meluas diterbitkan berbanding dengan terbitan kajian keberkesanan mindfulness sebagai salah satu strategi yang meningkatkan perhatian murid-murid di negara-negara lain (Napoli et al, 2005, Watier \& Dubois, 2016; Lim, \& Qu, 2017). Oleh itu, pengkaji ingin menjalankan kajian mindfulness dalam konteks sekolah rendah bagi meningkatkan perhatian murid-murid. 
Kajian ini bertujuan untuk mengkaji keberkesanan mindfulness dalam meningkatkan perhatian selektif. Dua soalan yang ingin difokuskan dalam kajian ini adalah apakah tahap perhatian selektif murid-murid sekolah rendah? Selain itu, pengkaji juga ingin mengetahui keberkesanan intervensi mindfulness dalam meningkatkan perhatian selektif murid rendah. Pengkaji telah memilih responden-responden yang terdiri daripada murid-murid sekolah rendah dan kajian ini telah membahagikan kumpulan kepada dua kumpulan iaitu kumpulan rawatan dan kumpulan kawalan. Kumpulan rawatan dan kumpulan kawalan akan menerima aktiviti yang lebih kurang sama dan mereka akan menjalankan ujian pra dan ujian pos untuk membandingkan kedua-dua kumpulan dengan instrumen pencarian visual conjunction dan ujian Stroop. Kedua-dua instrumen sering digunakan untuk mengukur perhatian selektif (Lobaugh et al, 1998; Prevor \& Diamond, 2005).

Penulisan artikel ini telah dibahagikan kepada beberapa bahagian. Dalam bahagian pertama, artikel ini akan berfokus kepada definisi perhatian selektif dan konsep mindfulness dalam kajian ini. Bahagian seterusnya akan juga akan membentangkan keputusan-keputusan yang signifikan daripada kajian-kajian lepas dalam bahagian tinjauan literatur. Bukan itu sahaja, penulisan seterusnya akan berfokus kepada metodologi yang digunakan untuk mendapatkan data supaya membuktikan keberkesanan intervensi mindfulness dalam peningkatan perhatian selektif. Selain itu, artikel ini juga akan membincangkan tentang dapatan kajian yang diperoleh. Akhirnya, pengkaji akan membuat kesimpulan tentang kajian yang dilaksanakan berserta dengan implikasi dapatan kajian ini.

\section{Sorotan Literatur}

Proses pembelajaran proses yang proses yang bersifat dua hala melibatkan penglibatan antara guru dan murid. Salah satu aspek yang masih kurang diberikan penekanan adalah bagaimana untuk meningkatkan kemahiran tumpuan. Kemahiran tumpuan merupakan salah satu elemen yang penting untuk mempertingkatkan kemahiran yang lain di sekolah seperti kemahiran membaca, mengira dan menulis (Ali \& Sahal, 2016). Dalam konteks pendidikan, perhatian merujuk kepada keupayaan seseorang individu itu memproses maklumat yang tertentu di dalam persekitaran kita (Price et al., 2011). Perhatian melibatkan pelbagai deria badan termasuk pendengaran, penglihatan, sentuhan, bau dan rasa. Semua sensasi yang dialami melibat perhatian seseorang. Dengan kata lain, sensasi badan berlaku apabila kita berfokus terhadap sesuatu deria badan yang dialami. Murid-murid yang sedemikian tidak dapat memberi tumpuan yang sepenuhnya kerana perhatian mereka senang teralih daripada rangsangan atau stimulus yang lain (Manisah \& Norizza, 2016; Agung, 2003). Murid-murid selalu diarah supaya memberi tumpuan di dalam kelas tetapi mereka jarang-jarang diajar bahawa cara untuk mengekalkan perhatian mereka atau memberi tumpuan di dalam kelas. Salah satu cabaran yang dihadapi oleh guru dalam mendidik murid adalah daya tumpuan murid-murid amat terhad dan tidak memberikan fokus di dalam kelas (Ali et al., 2016).

\section{Teknik Mindfulness}

Salah satu cabaran yang dihadapi oleh guru dalam mendidik murid yang berkualiti adalah daya tumpuan murid-murid amat terhad dan mereka tidak dapat berfokus dalam kelas (Ali et al., 2016). Kualiti pengajaran guru tidak terjamin kerana murid-murid tidak dapat berfokus apabila guru menyampaikan pengajaran di dalam kelas. Dalam kajian mindfulness, Kabat-Zinn (1993) merupakan salah satu penggerak amalan mindfulness yang terkenal di dunia. Beliau merupakan pengasas program MBSR (Mindfulness Based Stress Reduction). Dalam konsep mindfulness Kabat-Zinn, perkataan Mindfulness merujuk kepada kesedaran terhadap pengalaman sekarang (present moment) dan bertindak secara tanpa penghakiman (nonjudgemental manner). Dengan kata lain, amalan mindfulness dapat membantu seseorang berfokus kepada pengalaman mereka pada ketika itu dan mengakui segala perasaan dalaman supaya mereka tidak terganggu daripada pemikiran dan renungan yang berkaitan dengan peristiwa masa lepas dan masa depan (Crescentini et al., 2016). Pemikiran yang terlalu memfokuskan kepada peristiwaperistiwa yang telah berlalu dan pemikiran kepada apa yang akan berlaku pada masa akan menimbulkan kecelaruan dalam pemikiran murid yang secara tidak langsung, ia mampu mengganggu proses pembelajaran. Walaupun tiada satu justifikasi yang jelas dalam menggambarkan fikiran pelajar semasa 
mereka sedang mengikuti pdpc, tetapi guru berupaya untuk membantu pelajar dalam menyediakan fikiran mereka untuk memfokuskan kepada masa sekarang (present moment).

Latihan mindfulness telah memberi kesan yang positif terhadap pesakit yang menghadapi tekanan, kebimbangan, kemurungan dan gejala psikiatri) kerana amalan ini dapat membantu seseorang itu sentiasa menyedari bahawa dirinya berada pada masa ketika itu dengan sikap yang terbuka ((Kabat-Zinn, 1990; Brown \& Ryan, 2003). Intervensi-intervensi mindfulness seperti yoga dan meditasi tradisional memberi impak yang positif terhadap perkembangan emosi, fizikal dan psikologi (Hussain \& Schirda, 2015). Dalam bidang klinikal, prinsip mindfulness iaitu berfokus kepada masa sekarang dan penerimaan secara terbuka (bertindak secara tanpa penghakiman) digunakan untuk meningkatkan fungsi eksekutif dan regulasi perhatian. Oleh itu, kajian ini juga mengkaji tentang keberkesanan amalan mindfulness dalam meningkatkan perhatian murid dalam konteks Malaysia.

Dalam kajian peningkatan kemahiran perhatian dengan amalan mindfulness mendapati bahawa amalan dapat mengawal pemikiran dan tingkah laku yang impulsif. Tarrasch (2018) telah menjalankan satu kajian terhadap 101 orang murid di sekolah rendah dengan bengkel latihan mindfulness sepanjang 10 minggu. Tarrasch (2018) mendapati bahawa intervensi mindfulness segi telah meningkatkan perhatian selektif murid terhadap tugasan perhatian, iaitu Tugasan pencarian visual conjunction ( CVS). Tugasan CVS merupakan sejenis perisian komputer yang menguji tahap perhatian murid (Tarrasch, 2018). Mindfulness dapat menurunkan pemikiran dan tingkah laku murid yang impulsif dengan mengekalkan perhatian mereka kepada masa sekarang (present moment). Murid-murid yang mengamalkan amalan mindfulness lebih menyedari (self-awarenes) bahawa mereka perlu berfokus kepada matlamat (self goal) yang ditetapkan (Weare, 2013). Oleh itu, mindfulness boleh meningkatkan kemahiran perhatian dan prestasi akademik dengan mengawal pemikiran dan tingkah laku yang impulsif.

Dalam kajian Napoli (2009) menunjukkan bahawa Mindfulness dapat meningkatkan perhatian selektif murid. Beliau telah menjalankan satu kajian yang menggunakan tempoh masa sekurang-kurangnya 24 minggu untuk membantu 300 orang murid supaya mereka lebih menumpu perhatian dan berfokus di dalam sekolah dan dapatan kajian menunjukkan hubungan yang positif antara kumpulan rawatan dalam meningkatkan kemahiran perhatian selektif dengan amalan mindfulness. Teknik pernafasan mindfulness telah banyak menyumbang kepada kemahiran perhatian (Brave, 2001). Dalam aktiviti pernafasan, satu teknik pernafasan iaitu Counting breath telah diajar dalam kajian Napoli. Pernafasan Mindfulness mengajar murid-murid cara menangani dengan stres dan kebimbangan (anxiety) supaya mereka dapat berfokus dan memberi tumpuan di dalam kelas. Oleh itu, pernafasan Mindfulness merupakan salah satu teknik atau elemen yang penting untuk meningkatkan perhatian murid.

\section{Teori Perhatian Selektif}

Selain itu, salah satu teori perhatian yang penting adalah teori Anne Treisman. Model perhatian selektifnya adalah model yang diadaptasikan berdasarkan model Broadbent. Menurut Anne (1964), input deria yang tidak terkawal (unattended sensory inputs) akan dikurangkan dengan penapisan dari segi intensiti penerimaan. Proses Pelemahan input deria ini dikenali Attenuation, iaitu fungsi perhatian selektif mengambil bahagian (Sarah, 2013). Sebagai contoh, tiga sumber bunyi diterima di sebuah bilik berlaku secara rentak seperti bunyi televisyen, bunyi radio dan percakapan manusia. Walaupun seseorang itu berfokus kepada salah satu sumber bunyi seperti radio, maka penerimaan kedua-dua sumber bunyi akan dilemahkan tetapi input bunyi tersebut masih berlaku dan wujud di sini dan bukan dihilangkan semata-mata. Macleod (1991) mengatakan bahawa perhatian selektif merupakan sejenis kebolehan memilih sejenis rangsangan yang ingin difokuskan berdasarkan sensori-sensori badan dan mengabaikan rangsangan yang tidak relevan. Proses Attenuation berdasarkan teori Treisman (1964) merupakan proses melemahkan input-input yang tidak relevan. Teori ini diaplikasikan semasa pembentukan instrumen mengukur perhatian selektif murid-murid. Dalam kajian ini, pengkaji ingin mengukur tentang keberkesanan mindfulness dalam meningkatkan perhatian selektif murid-murid di sekolah. Teori Anne Treisman ini telah menjelaskan bahawa perhatian selektif merupakan penapisan input sensori iaitu proses Attenuation akan melemahkan input sensori yang tidak penting atau tidak relevan supaya individu itu dapat berfokus kepada maklumat yang penting. Dalam pengukuran perhatian selektif, pengkaji menggunakan teori untuk mereka cipta alat pengukuran perhatian selektif di mana alat pengukuran ini 
perlu bersifat distrator dan berkeupayaan untuk menguji tahap perhatian selektif murid-murid. Dalam kajian ini, murid-murid perlu berfokus dan hanya memberi respons yang sesuai seperti bertindak balas terhadap sasaran yang ditetapkan. Proses Attenuation berlaku semasa mereka dipapar dengan pelbagai rangsangan.

Pada asalnya, kebanyakan kajian Mindfulness telah berfokus kepada bidang klinikal seperti kesakitan klinikal ( Brown \& Ryan, 2003; Kabat, 1982), gangguan emosi (Miller et al., 1995; 2010) dan gangguan tidur (Howell et al., 2008; Black et al., 2015). Bukan itu sahaja, kajian-kajian mindfulness juga berfokus kepada peningkatan dari segi perkembangan kognitif (Cristiano et al., 2016) seperti fungsi eksekutif dan perhatian. Dalam kontek yang berbeza seperti kanak-kanak atau remaja, kajian juga menunjukkan pelbagai keputusan yang positif seperti meningkatkan kemahiran sosial, perhatian (Napoli et al., 2005) dan mengurangkan simptom kemurungan (Lee et al, 2008). Walaupun kajian-kajian demikian telah membuktikan keberkesanan Mindfulness terhadap pelbagai golongan yang berbeza seperti dewasa dan kanak-kanak, tetapi sebahagian kajian masih terdapat pelbagai limitasi. Sesetengah kajian tidak mempunyai kumpulan kawalan (Lee et al., 2008) dan mereka hanya membanding keputusan sebelum dan selepas sekumpulan responden sahaja. Bukan itu sahaja, kajian-kajian mindfulness terhadap kanakkanak telah melibatkan penyertaan ibu bapa(Napoli et al., 2005). Penilaian kajian itu yang mengambil kira laporan ibu bapa sebagai instrumen kajian juga mungkin menyebabkan bias tertentu kepada keputusan kajian. Dengan kata lain, kemungkinan persepsi ibu bapa berubah dan tidak bersifat begitu objektif kerana mereka telah menyertai dalam aktiviti-aktiviti berkenaan. Oleh itu, kajian ini akan mengujikan kanak-kanak dalam sekolah rendah dengan membandingkan kumpulan rawatan dan kumpulan kawalan tanpa melibatkan penyertaan ibu bapa. Pengumpulan data juga tidak melibatkan penilaian pihak ketiga seperti guru-guru atau ibu bapa, maka hanya mengkaji berdasarkan instrumeninstrumen berkomputer iaitu ujian Stroop dan ujian pencarian visual Conjunction (CVS).

\section{Metod Kajian}

Dalam kajian ini, penyelidik menggunakan kaedah kuantitatif untuk membuktikan bahawa intervensi mindfulness ini dapat memberi kesan kepada perhatian selektif. Kajian kuantitatif lebih berfokuskan kepada pendekatan deduktif. Pendekatan deduktif digunakan untuk membangun atau mengesahkan sesuatu teori yang dimulakan dengan konsep yang abstrak dan bertindak ke arah yang boleh mendapatkan bukti empirikal yang lebih konkrit (Neuman, 2014). Kajian ini dijalankan dalam bentuk eksperimental. Menurut Bell (2014), kajian eksperimental biasanya membuat perbandingan antara dua kumpulan, iaitu kumpulan rawatan dan kumpulan kawalan. Kajian eksperimental sesuai digunakan untuk mencari punca dan kesan di antara pemboleh ubah bebas dan pemboleh ubah bersandar dalam keadaan yang terkawal (Creswell, 2012). Kajian ini akan membahagikan dua kumpulan yang terdiri daripada murid-murid sebuah sekolah rendah dan kedua-dua kumpulan mempunyai ciri-ciri yang lebih kurang sama seperti umur, tahap IQ berdasarkan ujian mereka dan sebagainya. Responden-responden yang terpilih berdasarkan ciri-ciri yang lebih kurang kerana pengkaji ingin mengurangkan pengaruh daripada faktor-faktor extraneous. Faktor-faktor extraneous akan mempengaruhi hasil dapatan sesuatu kajian experimental dan mengakibatkan kajian tersebut tidak dapat mencerminkan skor yang tulen (Creswell, J. W., 2012).

\section{Populasi dan sampelkajian}

Kajian ini telah menggunakan pensampelan berstrata. Menurut Creswell (2012), kaedah pensampelan berstrata adalah responden-responden dipilih berdasarkan ciri-ciri yang tertentu. Kumpulan yang ingin dikaji dalam kajian ini adalah terdiri daripada murid-murid sebuah sekolah rendah di semenanjung Malaysia. Murid-murid yang terpilih untuk kajian ini adalah murid-murid tahun 6. Untuk mendapat hasilan kajian yang lebih tepat, kedua-dua kumpulan ,iaitu kumpulan rawatan dan kumpulan kawalan mempunyai ciri-ciri yang lebih kurang sama dari segi umur, tahap kecerdasan IQ (kedua-dua kumpulan terdiri daripada pencapaian akademik yang lebih tinggi). Sebanyak 22 orang murid tahun 6 telah dipilih dan diasingkan kepada dua kumpulan dengan bilangan yang sama. 


\section{Instrumen kajian}

Dua instrumen yang digunakan dalam kajian ini adalah ujian Stroop dan pencarian visual Conjuction (CVS). Ujian Stroop merupakan salah satu instrumen yang terkenal dan direka cipta oleh John Ridly Stroop pada tahun 1935. Secara ringkasnya, ujian Stroop ini terdiri daripada perkataan-perkataan warna seperti green, blue, red, yellow tetapi warna perkataan tersebut tidak kongruen dengan perkataannya. Dalam tugasan ini, responden ditunjuk dengan perkataan-perkataan seperti "red", "green", "blue" dan "yellow". Responden perlu menekan R untuk mewakili warna merah (red) berdasarkan cetakan warna perkataan tersebut seperti "green".

Instrumen kedua yang digunakan adalah pencarian visual conjunction (CVS). Instrumen ini memerlukan perhatian seseorang dengan kemahiran pengimbasan secara visual untuk mencari sesuatu ciri atau objek yang tertentu atau dikenali sebagai sasaran di antara objek-objek atau pengganggu yang lain (Treisman, 1980). Instrumen ini sesuai untuk mengkaji perhatian selektif secara visual (Lobaugh et al., 1998). Dalam instrumen tersebut, responden perlu mencari sasaran yang ditentu seperti bentuk atau warna. Ujian ini akan digabungkan dengan pengganggu yang lain, dikenali sebagai distracter. Dalam Ujian CVS, responden diminta untuk mencari huruf $\mathrm{T}$ yang berwarna oren seperti $\mathrm{T}$. Huruf $\mathrm{T}$ yang berwarna biru atau huruf T yang terbalik dijadikan pengganggu. Responden perlu menekan butang spacebar sekiranya huruf $\mathrm{T}$ yang berwarna oren terwujud di dalam gambar dan sekiranya tidak wujudnya sasaran yang ditetapkan dalam paparan itu, maka responden tidak perlu menekan apa-apa.

Salah satu sebab penyelidik menggunakan instrumen CVS selain daripada ujian Stroop adalah untuk meningkatkan kesahan kajian ini. Menurut kajian Prevor dan Diamond (2005), hasil dapatan instrumen ujian Stroop terpengaruh sekiranya responden yang dikaji tidak boleh membaca perkataan yang ditunjukkan kerana perkataan warna itu tidak dapat dijadikan sebagai pengganggu kepada responden. Perisian-perisian tersebut menggunakan beberapa bahasa pengaturcaraan seperti Javascript, Linux, Ruby dan sebagainya. Dalam kajian eksperimen ini, reka bentuk ujian pra-pos telah digunakan kepada kumpulan rawatan dan kumpulan kawalan.

\section{Kebolehpercayaan dan Kesahan Instrumen Kajian}

Kajian ini akan menggunakan kesahan pakar. Penyelidik telah menjalankan proses kesahan kandungan dengan menggunakan khidmat sekurang-kurang dua pakar dalam psikologi atau pendidikan. Kriteria pemilihan pakar adalah berdasarkan pengalaman mereka dalam bidang berkenaan seperti mempunyai pengalaman 10 tahun. Penyelidik akan menunjukkan kedua-dua perisian serta prosedur menjalankan kajian ini kepada pakar-pakar berkenaan untuk menyemak keberkesanan pengukurannya. Dari segi kebolehpercayaan, kedua-dua instrumen akan diukur dengan kaedah ujian pra-pasca (test-retest). Keduadua ujian ini akan diedarkan kepada sekurang-kurangnya 10 orang murid sekolah rendah di Klang untuk mengukur ketekalan instrumen yang digunakan. Selepas seminggu, responden yang sama akan diuji semula untuk membuat perbandingan dengan keputusan yang pertama kali.

\section{Prosedur Kajian}

Kajian ini menggunakan reka bentuk Ujian Pra-Pasca. Tujuannya adalah reka bentuk ini dapat membantu pengkaji mengetahui keberkesanan pemboleh ubah bebas terhadap pemboleh ubah bersandar. Dalam kajian ini, dua kumpulan responden akan diagih secara rawak dan mereka diberi kedua-dua ujian tersebut untuk menentukan tahap perhatian selektif mereka sebagai ujian pra.

Reka bentuk kajian ini diadaptasi daripada model kajian Lim dan Qu (2017). Kajian ini akan dijalankan dengan konsep Brief Mindfulness Exercise di mana kajian ini hanya dijalankan dalam satu sesi dengan tempoh 30 minit. Disebabkan latihan Mindfulness difokuskan kepada kanak-kanak sekolah rendah, latihan akan dijalankan dalam bentuk permainan supaya mereka lebih berminat dan berasa seronok semasa menjalankan aktiviti-aktiviti yang direka cipta. Aktiviti-aktiviti Mindfulness yang direka cipta daripada adaptasi daripada intervensi Phang, C. K., (2016) dengan terbitan NOW - Who Wants To Learn MINDFULGym?: 12 Mindful Tools For Stress Reduction \& Wellness. Dalam latihan satu sesi, aktiviti 
mindfulness akan dijalankan dalam masa 30 minit kerana kanak-kanak mempunyai masalah tumpuan untuk masa yang panjang (Tarrasch, 2018). Program ini akan dijalankan dalam tempoh 2 minggu. Minggu pertama akan digunakan untuk ujian pra di antara kumpulan rawatan dan kawalan. Taklimat akan diberikan kepada kumpulan rawatan tentang program intervensi tersebut dan mendapat kebenaran daripada ibu bapa mereka sebelum menjalankan intervensi.

Dalam latihan kumpulan rawatan, jurulatih membimbing kanak-kanak tentang aktiviti-aktiviti mindfulness. Latihan mindfulness telah dibahagikan kepada 3 bahagian iaitu regangan mindfulness, latihan pendengaran mindfulness dan latihan pernafasan mindfulness. Dalam aktiviti pertama, jurulatih meminta responden untuk berfokus kepada pergerakan yang dilakukan dan juga berfokus kepada pernafasan dalam masa 10 minit. Kemudian, kanak-kanak akan difokuskan kepada pendengaran mindfulness di mana jurulatih akan meminta responden berfokus kepada bunyi loceng yang dimainkan. Sekiranya bunyi loceng dihentikan maka mereka perlu mengangkat tangan. Latihan yang terakhir adalah latihan pernafasan. Responden diminta untuk berfokus kepada pernafasan mereka dan membilang pernafasan mereka sehingga 10 dan mengulangi perbuatan ini dalam keadaan duduk yang selesa. Sepanjang proses ini, responden sentiasa diingatkan bahawa sekiranya mereka menghadapi keadaan tidak berfokus (attention wandered) adalah normal dan mereka hanya perlu mengembalikan perhatian mereka kepada latihan yang dijalankan.

Bagi latihan kumpulan kawalan, responden diminta untuk menjalankan regangan biasa. Mereka ditunjukkan video dan menjalankan regangan yang mudah di depan komputer riba. Dalam aktiviti kedua, mereka diminta untuk mempelajari tarian cawan. Dalam masa 10 minit, mereka ditunjukkan dengan video dan mereka perlu mengikut irama muzik dan melakukan pergerakan yang tertentu dengan menggunakan cawan. Manakala, aktiviti yang terakhir adalah aktiviti membilang. Responden diminta untuk menulis nombor 1 hingga 100 dalam masa 5 minit. Selepas aktiviti-aktiviti dijalankan kepada kedua-dua kumpulan ,maka ujian pos akan dijalankan bagi kumpulan rawatan dan kawalan.

\section{Hasil Kajian}

\section{Analisis Ujian Stroop}

Selepas intervensi mindfulness, masa tindak balas kumpulan rawatan telah menurun daripada 126ms kepada $113.55 \mathrm{~ms}$ manakala masa tindak balas kumpulan kawalan bertambah daripada $86.73 \mathrm{~ms}$ kepada 93.09ms.

Rajah 1: Perbandingan ujian pra dan ujian pos kumpulan rawatan dan kumpulan kawalan dengan menggunakan ujian Stroop bagi mengukur masa tindak balas

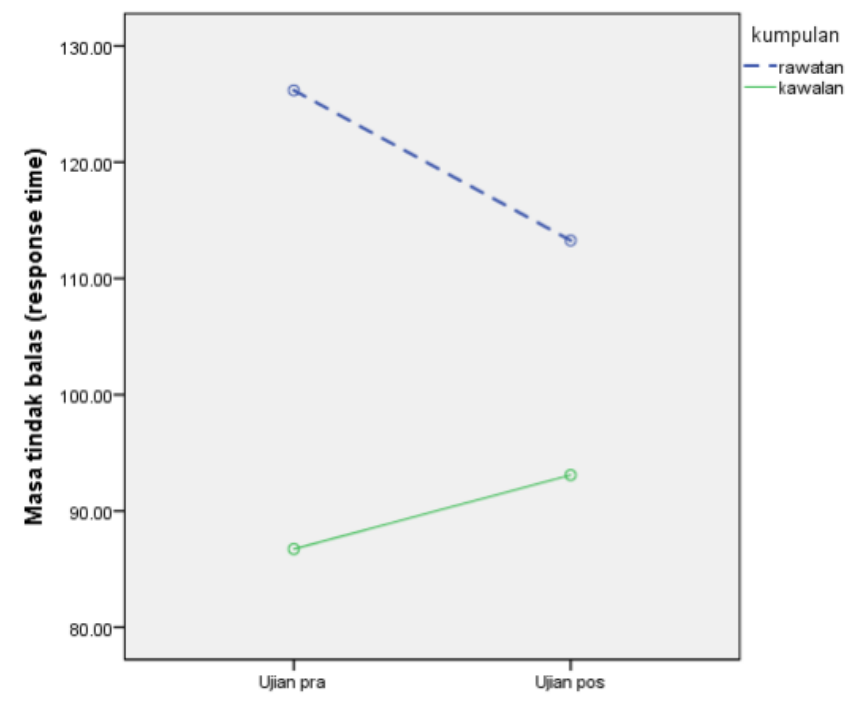


Dalam ujian Stroop, kumpulan rawatan boleh dilihat bahawa bertindak lebih cepat berbanding dengan kumpulan kawalan selepas menerima intervensi mindfulness dari segi perbandingan masa tindak balas. Dalam ujian Stroop, kumpulan rawatan boleh dilihat bahawa bertindak lebih cepat berbanding dengan kumpulan kawalan selepas menerima intervensi mindfulness dari segi perbandingan masa tindak balas. Oleh itu, gambar rajah 1 menunjukkan keadaan penurunan berlaku pada ujian pos manakala kumpulan kawalan menggunakan masa yang lebih semasa menjawab ujian ini pada ujian pos.

Dari segi perbandingan kadar kesilapan (error rate), kadar kesilapan kumpulan rawatan telah meningkat daripada $2.72 \%$ kepada $4.77 \%$ manakala kadar kesilapan kumpulan kawalan meningkatkan daripada $10.68 \%$ kepada $12.05 \%$. Dalam perbandingan keputusan secara deskriptif, walaupun keputusan menunjukkan kedua-dua kumpulan telah meningkatkan dari kadar kesilapan tetapi kadar kesilapan kumpulan kawalan lebih tinggi berbanding dengan kumpulan rawatan dalam kedua-dua ujian. Rajah 2 menunjukkan hubungan keputusan ujian pra dan ujian pos bagi kumpulan rawatan dan kumpulan kawalan bagi error rate dalam ujian stroop.

Rajah 2: Perbandingan ujian pra dan ujian pos kumpulan rawatan dan kumpulan kawalan dengan menggunakan ujian Stroop bagi mengukur kadar kesilapan

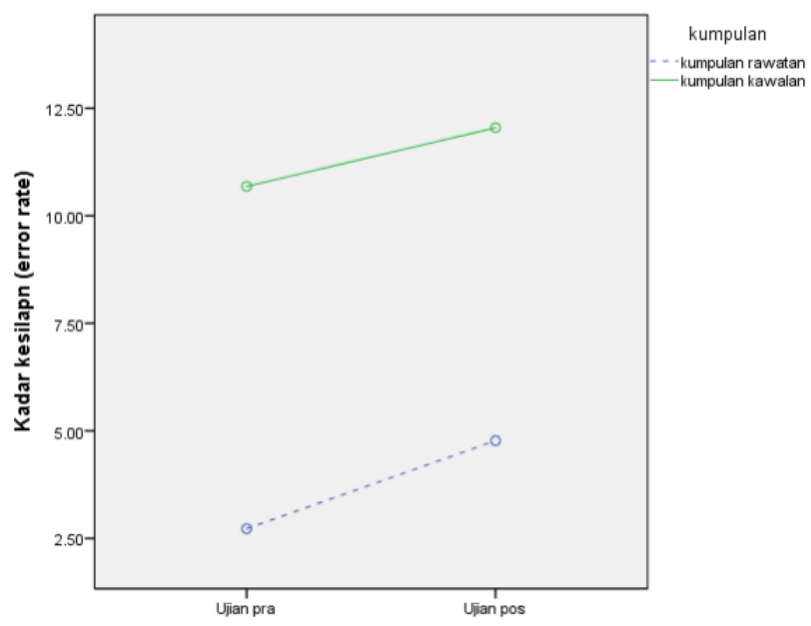

\section{Analisis Ujian Pencarian Visual Conjunction (CVS)}

Dalam ujian CVS, responden perlu mencari huruf $\mathrm{T}$ yang berwarna oren seperti $\mathrm{T}$ dan mengabaikan pengganggu item yang lain. Dalam ujian CVS, paparan item (display item) telah dibahagikan kepada 4 katogori, iaitu 5 display, 10 display, 15 display dan 20 display. Pencapaian dari segi masa tindak (response time) akan dijadikan semakin bertambah apabila display item semakin banyak (Tsal et al. 2005) kerana semakin banyak display item dipaparkan memerlukan masa yang panjang untuk mencari sasaran yang ditentukan.

Rajah 3 menunjukkan keputusan min response time yang dibandingkan di antara kumpulan rawatan dan kumpulan kawalan. Dapatan kajian menunjukkan bahawa kedua-dua kumpulan telah meningkatkan pencapaian mereka dari segi response time dalam $C V S$, namun kumpulan rawatan boleh dilihat bahawa mereka menggunakan masa yang lebih singkat atau dikatakan bertindak dengan lebih cepat berbanding dengan masa yang digunakan pada ujian pra.

Rajah 4 menunjukkan hubungan keputusan ujian pra dan ujian pos bagi kumpulan rawatan dan kumpulan kawalan bagi error rate ujian CVS. Dari segi perbandingan kadar kesilapan (error rate), Dapatan kajian menunjukkan kadar kesilapan kumpulan rawatan telah menurun dalam ujian pos manakala kadar kesilapan kumpulan kawalan telah meningkatkan pada ujian pos. Selepas intervensi mindfulness, kadar kesilapan kumpulan rawatan telah menurun daripada $0.029 \%$ kepada $0.024 \%$ manakala kadar kesilapan kumpulan kawalan meningkatkan daripada $0.024 \%$ kepada $0.026 \%$. 
Rajah 3: Perbandingan ujian pra dan ujian pos kumpulan rawatan dan kumpulan kawalan dengan menggunakan ujian $C V S$ bagi mengukur masa tindak balas

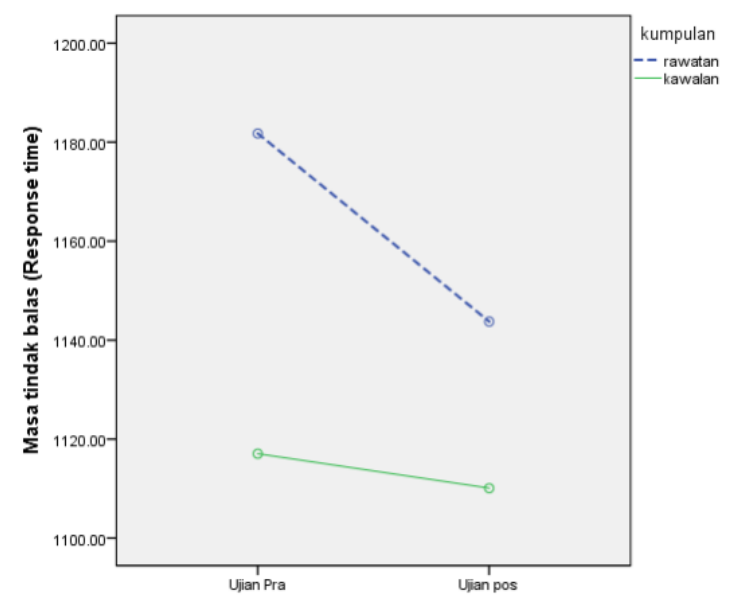

Rajah 4: Perbandingan ujian pra dan ujian pos bagi kumpulan rawatan dan kumpulan kawalan dengan menggunakan ujian $C V S$ bagi kadar kesilapan

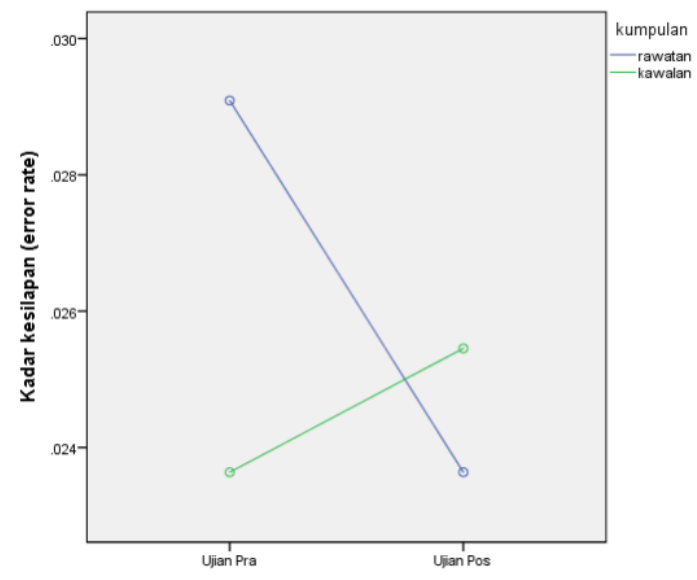

\section{Analisis Inferensi}

Kajian ini telah menggunakan model split-plot ANOVA untuk mengkaji tentang keberkesanan intervensi mindfulness terhadap kumpulan rawatan dan juga mengkaji tentang kesan-kesan aktiviti alternatif terhadap kumpulan kawalan. Keputusan SPSS menunjukkan interaction effect di antara kumpulan dan response time ujian Stroop mempunyai nilai yang signifikan iaitu $\mathrm{F}(1,20)=17.631$, p<.05). Keputusan SPSS menunjukkan interaction effect di antara kumpulan dan response time ujian CVS mempunyai nilai yang signifikan iaitu $\mathrm{F}(1,20)=4.98, \mathrm{p}<.05)$. Dengan kata lain, terdapat perbezaan antara kumpulan rawatan dan kumpulan kawalan dari segi response time dalam ujian CVS dan ujian Stroop. Hal ini menunjukkan intervensi mindfulness dibuktikan dapat memberi kesan atas perbandingan antara kumpulan rawatan dan kawalan dari segi response time.

Keputusan SPSS menunjukkan interaction effect antara kumpulan dan error rate ujian Stroop tidak mempunyai nilai yang signifikan iaitu $\mathrm{F}(1,20)=0.124, \mathrm{p}>.05)$. Keputusan SPSS menunjukkan interaction effect di antara kumpulan dan error rate ujian $C V S$ tidak mempunyai nilai yang signifikan iaitu $\mathrm{F}(1,20)=0.124, \mathrm{p}>.05)$. Dengan kata lain, hipotesis null tidak ditolak, tidak terdapat perbezaan antara kumpulan rawatan dan kumpulan kawalan dari segi response time dalam ujian CVS dan Stroop. Hal ini menunjukkan intervensi mindfulness tidak dibuktikan memberi kesan atas perbandingan antara kumpulan rawatan dan kawalan dari segi error rate. 


\section{Perbincangan Kajian}

Keputusan kajian telah menunjukkan bahawa intervensi mindfulness dapat meningkatkan masa tindak balas murid sekolah rendah dengan menggunakan ujian Stroop dan ujian CVS. Kedua-dua ujian ini telah menguji keupayaan murid-murid dari segi keupayaan mengawal tindak balas atau dikenali sebagai ability of inhibit responses. Keupayaan ini adalah indikator kepada tingkah laku yang impulsif (Egelan \& Kovalik, 2010). Intervensi mindfulness ini dapat mengawal tingkah laku atau pemikiran yang impulsif ini dan mengekal perhatian mereka kepada masa sekarang iaitu present moment. Perkara ini dapat membantu mereka untuk bertindak secara lebih tenang dan less impulsivity berbanding dengan kumpulan kawalan. Perkara ini disokong oleh Tarrasch (2018), iaitu latihan mindfulness dapat membantu seseorang dari segi self-control dan less impulsivity kerana mereka terlatih untuk paying attention on purpose seperti present moment, penafasan.

Dapatan kajian ini menunjukkan bahawa tidak mempunyai nilai yang signifikan di antara kumpulan ( $\mathrm{P}>0.05)$ bagi kadar kesilapan. Keputusan ini mungkin dipengaruh oleh gender differences atau core personality traits. Kajian ini tidak berfokus kepada kedua-dua aspek ini kerana responden-responden terdiri kaedah pensampelan secara rawak. Menurut kajian Thomas dan Atkinson (2016), perbezaan jantina dan personality traits mungkin menyumbang kepada kesan-kesan yang diberi oleh intervensi mindfulness. Core personality trait seperti agreeableness, openness, conscientiouness akan mempengaruhi kesan mindfulness terhadap individu yang berbeza. Walaubagaimanapun, penjelasan ini memerlukan saiz pensampelan yang lebih besar untuk menjawab faktor-faktor berkenaan. Selain itu, keputusan ini selari dengan kajian (Fan, Y., et al, 2014) iaitu intervensi mindfulness tidak menunjukkan keputusan yang signifikan pada aspek kadar kesilapan. Fan, Y., et al menjelaskan fenomena ini telah menunjukkan kedua-dua kumpulan menjawab soalan dengan berhati-hati dengan kadar kecuaian yang amat rendah. Berdasarkan dapatan kajian ini, kadar kesilapan kedua-dua kumpulan tidak melebihi $1 \%$ dalam ujian CVS.

Dapatan kajian ini menunjukkan bahawa intervensi mindfulness memberi kesan yang positif terhadap perhatian selektif berbanding dengan aktiviti yang alternatif di bawah pengukuran ujian Stroop dan CVS terutamanya keputusan yang signifikan terhadap masa tindak balas bagi kumpulan rawatan. Keputusan ini selaras dengan keputusan yang didapati oleh kajian-kajian yang mindfulness terhadap kemahiran perhatian (Napoli et al, 2005; Flook et al., 2010; Felver et al, 2017) iaitu kanak-kanak menunjukkan kemajuan dari segi perhatian selepas menerima latihan mindfulness. Dapatan kajian membuktikan bahawa konsep mindfulness dapat membantu murid-murid untuk berfokus kepada sesuatu objek seperti pernafasan, suara dan pergerakan badan (Malinowski, 2013). Latihan-latihan sedemikian dapat mengurangkan masalah mind-wandering dan membantu sesorang itu dari segi peningkatan perhatian selektif. Dengan ini, murid-murid kumpulan rawatan dapat bertindak dengan lebih cepat dalam ujian Stroop dan ujian CVS kerana kedua-dua ujian ini memerlukan keupayaan berfokus kepada rangsangan yang dikehendaki (Tsal et al. 2005).

Dapatan kajian juga menjelaskan tentang keadaan yang dikemukakan dalam kajian Baumgartner dan Sumter (2017) iaitu punca masalah perhatian adalah overstimulating dan excitement. Berbanding dengan kumpulan yang kawalan, kumpulan mindfulness lebih berfokus semasa ujian yang diberikan, kumpulan rawatan bertindak dengan lebih cepat dari segi response time dan mereka melakukan kesilapan yang lebih rendah berbanding dengan kumpulan kawalan. Salah satu prinsip mindfulness yang ditegaskan adalah non judgemental di mana segala perasaan atau pemikiran dalaman akan diterima secara neutral. Dengan kaedah sedemikian, konsep mindfulness dapat membantu mereka untuk mengatasi excitement dan menjadikan mereka lebih berfokus dan bertenang walaupun ujian-ujian yang disebabkan berunsur excitement disebabkan had masa dan memerlukan kadar menjawab soalan yang cepat.

\section{Kesimpulan}

Secara kesimpulannya, hasil kajian menunjukkan bahawa intervensi mindfulness berkesan terhadap perhatian murid sekolah rendah. Berdasarkan keputusan kajian ini, pengkaji bercadang intervensi 
mindfulness sesuai dijalankan untuk murid-murid sekolah rendah. Pendidik juga boleh mengajar muridmurid tentang teknik ini sebelum mereka menduduki sesuatu peperiksaan supaya mereka boleh menjadi lebih berfokus dan bertenang. Walaupun kajian mindfulness ini berfokus kepada kanak-kanak yang bukan berkeperluan khas, tetapi aktiviti sedemikian dipercayai juga memberi kesan yang positif kepada kanak-kanak berkeperluan khas dari segi perhatian. Aktiviti-aktiviti mindfulness boleh digunakan sebagai teknik-teknik berfokus kepada kanak-kanak berkeperluan khas seperti ADHD. Charach et al. (2014) menyatakan bahawa perubatan yang digunakan untuk merawat kanak-kanak ADHD akan membawa kesan-kesan sampingan yang tidak menyenangkan. Teknik mindfulness boleh dijadikan salah satu teknik yang alternatif untuk membantu mereka sekiranya mereka menghadapi masalah menumpu perhatian di dalam kelas.

Kajian ini terdapat beberapa limitasi. Pertama, responden-responden yang dipilih tidak merangkumi umur-umur yang lain. Kajian-kajian lain menunjukkan bahawa attentional capacities amat bergantung kepada umur yang berlainan (Klenberg et al., 2001). Kajian ini tidak mengumpul data daripada pihak ketiga seperti guru-guru atau ibu bapa tentang perubahan mereka dari segi perhatian dalam kehidupan seharian. kaedah kajian boleh mengunakan mixed-method seperti temu bual atau soal selidik supaya mendapatkan keputusan yang lebih menyeluruh. Ketiga adalah pengukuran ujian boleh mempertimbangkan domain-domain yang lain seperti pencapaian, masalah emosi dan sebagainya. Faktor-faktor sedemikian juga dipercayai akan mempengaruhi pencapaian mereka dari segi perhatian.

\section{Rujukan}

Ahmadi, A.; Mustaffa, M.; Haghdoost, A.; Alavi, M. (2014). Mindfulness and Related Factors among Undergraduate Students. Procedia Soc. Behav. Sci, 159, 20-24.

Ali, M. M., \& Sahal, N. (2016). Intervensi Meningkatkan Tumpuan dalam Pembelajaran Murid Bermasalah Pembelajaran. Malaysian Journal of Education (0126-6020), 41(1).

Baumgartner, S. E., \& Sumter, S. R. (2017). Dealing with media distractions: an observational study of computer-based multitasking among children and adults in the Netherlands. Journal of Children and Media, 11(3), 295-313.

Black, D. S. (2011). A brief definition of mindfulness. Behavioral Neuroscience, 7(2), 109. Boyle, C. A., Boulet, S., Schieve, L. A., Cohen, R. A., Blumberg, S. J., Yeargin-Allsopp,

Bell, J. (2014). Doing Your Research Project: A guide for first-time researchers. McGraw-Hill Education (UK).

Brave Heart, M. Y. H. (2001). Culturally and historically congruent clinical social work assessment with Native clients. In R. Fong \& S. B. C. L. Furuto (Eds.), Cultur-ally competent practice: Skills, interventions, and evaluations (pp. 163-177). Boston: Allyn \& Bacon.

Brown, K.W. \& Ryan, R.M. (2003). The benefits of being present: Mindfulness and its role in psychological well-being. Journal of Personality and ScialPsychology, 84, 822-848.

Bruya, B. (Ed.). (2010). Effortless attention: A new perspective in the cognitive science of attention and action. MIT Press.

Cooley, E. L., \& Morris, R. D. (1990). Attention in children: A neuropsychologically based model for assessment.

Charach, A., Yeung, E., Volpe, T., \& Goodale, T. (2014). Exploring stimulant treatment in ADHD: narratives of young adolescents and their parents. BMC psychiatry, 14(1), 1-11.

Crescentini, C., Capurso, V., Furlan, S., \& Fabbro, F. (2016). Mindfulness-oriented meditation for primary school children: Effects on attention and psychological well-being. Frontiers in psychology, 7, 805 .

Egeland, J., \& Kovalik-Gran, I. (2010). Measuring several aspects of attention in one test: The factor structure of Conners's Con- tinuous PerformanceTest. Journal of Attention Disorders, 13(4), 339-346. https://doi.org/10.1177/1087054708323019.

Fan, Y., Tang, Y. Y., Tang, R., \& Posner, M. I. (2014). Short term integrative meditation improves resting alpha activity and stroop performance. Applied psychophysiology and biofeedback, 39(34), 213-217.

Howell, A. J., Digdon, N. L., Buro, K., \& Sheptycki, A. R. (2008). Relations among mindfulness, wellbeing, and sleep. Personality and Individual Differences, 45(8), 773-777. 
Jensen, C. G., Vangkilde, S., Frokjaer, V., \& Hasselbalch, S. G. (2012). Mindfulness training affects attention - or is it attentional effort? Journal of Experimental psychology: General, 141(1), 106123. https://doi.org/10.1037/a0024931.

Kabat-Zinn, J. (2009). Wherever you go, there you are: Mindfulness meditation in everyday life. Hachette Books.

Klenberg, L., Korkman, M., \& Lahti-Nuuttila, P. (2001). Differential development of attention and executive functions in 3-to 12-year-old Finnish children. Developmental neuropsychology, 20(1), 407-428.

Lee, J., Semple, R. J., Rosa, D., and Miller, L. (2008). Mindfulness-based cognitive therapy for children: results of a pilot study. J. Cogn. Psychother. 22, 15-28. doi: 10.1891/0889.8391.22.1.15

Lobaugh, N. J., Cole, S., \& Rovet, J. F. 1998. Visual search for features and conjunctions in development. Canadian Journal of Experimental Psychology/Revue canadienne de psychologie expérimentale, 52(4), 201.

Lim, X., \& Qu, L. (2017). The effect of single-session mindfulness training on preschool children's attentional control. Mindfulness, 8(2), 300-310.

Moore, A., \& Malinowski, P. (2009). Meditation, mindfulness and cognitive flexibility. Consciousness and cognition, 18(1), 176-186.

Nachiappan, S., Munovah, R. M. E., Abdullah, N., \& Suffian, S. (2017). Perkembangan kognisi dalam kanak-kanak prasekolah melalui teknik bermain. Jurnal Pendidikan Awal Kanak-kanak Kebangsaan, 6(1), 34-44.

Napoli, M., Krech, P. R., \& Holley, L. C. (2009). " Mindfulness training for elementary school students: The attention academy:" Erratum.

Posner, M. I., \& Boies, S. J. (1971). Components of attention. Psychological review, 78(5), 391.

Neuman, W. L. (2014). Basics of social research. Pearson/Allyn and Bacon.

Phang, C. K., Chiang, K. C., Ng, L. O., Keng, S. L., \& Oei, T. P. S. (2016). Effects of brief group mindfulness-based cognitive therapy for stress reduction among medical students in a Malaysian university. Mindfulness, 7(1), 189-197.

Posner, M. I., \& Boies, S. J. (1971). Components of attention. Psychological review, 78(5), 391.

Prakash, R. S., Hussain, M. A., \& Schirda, B. (2015). The role of emotion regulation and cognitive control in the association between mindfulness disposition and stress. Psychology and aging, 30(1), 160.

Prevor, M. B., \& Diamond, A. 2005. Color-object interference in young children: A Stroop effect in children 31/2-61/2 years old. Cognitive development, 20(2), 256-278.

Price, M., Handley, K., \& Millar, J. (2011). Feedback: Focusing attention on engagement. Studies in higher education, 36(8), 879-896.

Sreenivasan, K. K., \& Jha, A. P. (2007). Selective attention supports working memory maintenance by modulating perceptual processing of distractors. Journal of cognitive neuroscience, 19(1), 32-41.

Solso, R. L., MacLin, M. K., \& MacLin, O. H. (2005). Cognitive psychology. Pearson Education New Zealand.

Su, Y. W., \& Swank, J. M. (2019). Attention Problems and Mindfulness: Examining a School Counseling Group Intervention With Elementary School Students. Professional School Counseling, 22(1), 2156759X19850559.

Tarrasch, R. (2018). The effects of mindfulness practice on attentional functions among primary school children. Journal of Child and Family Studies, 27(8), 2632-2642.

Thomas, G., \& Atkinson, C. (2016). Measuring the effectiveness of a mindfulness-based intervention for children's attentional functioning. Educational \& Child Psychology, 33(1), 51-64.

Treisman, A. M. (1964). Selective attention in man. British medical bulletin, 20(1), 12-16. 